\title{
EFFECTS OF FREEZING POINT DEPRESSION AND FLUID TO GAS RATIO ON FERTILITY OF FOWL SPERMATOZOA STORED IN $\mathrm{CO}_{2}$ EXTENDERS
}

\author{
G. G. HARRIS, JR AND T. D. HOBBS* \\ Department of Animal Sciences, University of Arkansas, \\ Fayetteville, Arkansas, U.S.A. \\ (Received 11th August 1967, revised 3rd February 1968)
}

Summary. Fowl semen was diluted four-fold with carbonated extenders varying in freezing point depression $(\Delta)$ and $\mathrm{CO}_{2}$ level. It was stored for $24 \mathrm{hr}$ at $2^{\circ} \mathrm{C}$ with fluid to gas ratios in containers varying between $1: 0$ to $1: 16 \mathrm{v} / \mathrm{v}$.

Highest average fertility $(87 \%)$ was obtained with spermatozoa stored in a carbonated citrate extender containing $0.8 \mathrm{~g} \mathrm{CO}_{2} / 100 \mathrm{ml}$ $\left(\Delta-0.69^{\circ} \mathrm{C}\right)$ and in a container with a fluid to gas ratio of $1: 7 \cdot 2$.

The best fertility in all experiments was obtained with semen stored in extenders varying in $\Delta$ from -0.63 to $-0.75^{\circ} \mathrm{C}$. Fertility was significantly reduced by storage of spermatozoa in a filled container without any gas space.

\section{INTRODUCTION}

The optimum freezing point depression $(\Delta)$ of extenders for the preservation of fowl semen has not been established. Wilcox \& Shaffner (1957) reported that fowl spermatozoa retained their full fertilizing ability over a wide range of salt concentrations $\left(\Delta-0.455\right.$ to $\left.-0.736^{\circ} \mathrm{C}\right)$. However, fertility was maximum when the $\Delta$ of the phosphate buffer was between -0.607 and $-0.639^{\circ} \mathrm{C}$. In contrast, Yamane, Tsukunaga \& Takahashi (1962) noted a marked improvement in fertility of fowl spermatozoa that were stored in a hypertonic yolkcitrate extender $\left(\Delta-1.039^{\circ} \mathrm{C}\right)$. In agreement with these findings, Hobbs \& Harris (1963a, b) showed that best fertility was obtained using fowl spermatozoa that had been stored in hypertonic non-carbonated $\left(\Delta-0.79^{\circ} \mathrm{C}\right)$ and carbonated $\left(\Delta-1.06^{\circ} \mathrm{C}\right)$ citrate extenders. The extenders containing carbon dioxide were significantly superior in maintaining the fertilizing capacity of fowl spermatozoa. Carbonated citrate extenders with a $\Delta$ of $-0.91^{\circ} \mathrm{C}$ gave highest fertility for stored turkey spermatozoa (Harris, Hobbs, Brown \& Warren, 1963).

In previous studies at this laboratory, large amounts of $\mathrm{CO}_{2}$ were evolved from carbonated extenders and it was necessary to handle the solutions in the cold in order to prevent excessive foaming. The need arose for a more practical

* Present address: Elanco Products Co., Indianapolis, Indiana. 
procedure using an extender containing small amounts of $\mathrm{CO}_{2}$ which would permit the handling of extender ingredients at room temperature. The present study was conducted to determine the effects on fertility of freezing point depression, $\mathrm{CO}_{2}$ level and ratio of fluid to gas space in a container using a handling procedure operating at room temperature.

\section{MATERIALS AND METHODS}

Stock solutions of sodium citrate $(0.1 \mathrm{~g} / \mathrm{ml})$, citric acid $(0.1 \mathrm{~g} / \mathrm{ml})$ and sodium bicarbonate $(0.05 \mathrm{~g} / \mathrm{ml})$ were used in mixing the extenders (Table 1$)$. The

TABLE 1

COMPOSITION OF GARBON DIOXIDE EXTENDERS*

\begin{tabular}{|c|c|c|c|c|c|}
\hline $\begin{array}{c}\text { Extender } \\
\text { No. }\end{array}$ & $\begin{array}{l}\text { Freezing point } \\
\text { depression } \\
\left({ }^{\circ} \mathrm{C}\right)\end{array}$ & $\begin{array}{c}\mathrm{CO}_{2} \text { level } \\
(\mathrm{g} / 100 \mathrm{ml})\end{array}$ & $\begin{array}{c}\text { Sodium } \\
\text { citrate } \\
(\mathrm{g} / 100 \mathrm{ml})\end{array}$ & $\begin{array}{c}\text { Sodium } \\
\text { bicarbonate } \\
(\mathrm{g} / 100 \mathrm{ml})\end{array}$ & $\begin{array}{c}\text { Citric } \\
\text { acid } \\
(\mathrm{g} / 100 \mathrm{ml})\end{array}$ \\
\hline $\begin{array}{r}1 \\
2 \\
3 \\
4 \\
5 \\
6 \\
7 \\
8 \\
9 \\
10 \\
11 \\
12 \\
13 \\
14 \\
15\end{array}$ & $\begin{array}{l}-0.82 \\
-0.75 \\
-0.68 \\
-0.62 \\
-0.79 \\
-0.72 \\
-0.63 \\
-0.56 \\
-1.02 \\
-0.89 \\
-0.75 \\
-0.69 \\
-0.62 \\
-0.53 \\
-0.44\end{array}$ & $\begin{array}{l}0.2 \\
0.2 \\
0.2 \\
0.2 \\
0.4 \\
0.4 \\
0.4 \\
0.4 \\
0.8 \\
0.8 \\
0.8 \\
0.8 \\
0.8 \\
0.8 \\
0.8\end{array}$ & $\begin{array}{l}3.94 \\
3.50 \\
3.04 \\
2.60 \\
2.94 \\
2.50 \\
2.05 \\
1.61 \\
3.57 \\
2.68 \\
1.79 \\
1.35 \\
0.90 \\
0.46 \\
0.02\end{array}$ & $\begin{array}{l}0.38 \\
0.38 \\
0.38 \\
0.38 \\
0.76 \\
0.76 \\
0.76 \\
0.76 \\
1.53 \\
1.53 \\
1.53 \\
1.53 \\
1.53 \\
1.53 \\
1.53\end{array}$ & $\begin{array}{l}0.29 \\
0.29 \\
0.29 \\
0.29 \\
0.58 \\
0.58 \\
0.58 \\
0.58 \\
1 \cdot 16 \\
1 \cdot 16 \\
1 \cdot 16 \\
1 \cdot 16 \\
1 \cdot 16 \\
1 \cdot 16 \\
1 \cdot 16\end{array}$ \\
\hline
\end{tabular}

* Oxytetracycline $(40 \mathrm{mg} / 100 \mathrm{ml})$ and dihydrostreptomycin sulphate $(200 \mathrm{mg} / 100 \mathrm{ml})$ were added.

antibiotic stock solution contained $1.26 \mathrm{mg} / \mathrm{ml}$ oxytetracycline and $6.30 \mathrm{mg} / \mathrm{ml}$ dihydrostreptomycin sulphate. The appropriate quantities of sodium citrate, sodium bicarbonate and antibiotic solutions were pipetted into a brown bottle. The bottle was capped with a screw-on cap with a rubber liner and solutions mixed by gentle swirling. The brown bottles had a total capacity of 13.0 , 34.4 or $63.8 \mathrm{ml}$ which permitted variable fluid (diluted semen) to gas space ratios from 1:0 to $1: 16 \mathrm{ml}$. All solutions were handled at room temperature $\left(27\right.$ to $\left.30^{\circ} \mathrm{C}\right)$.

Pooled semen samples were collected from twenty-four New Hampshire males by the method of Burrows \& Quinn (1937). Samples were pipetted into each brown bottle, the citric acid was added and the bottles were immediately capped and swirled to provide adequate mixing. The semen samples were diluted four-fold and stored for $24 \mathrm{hr}$ at $2^{\circ} \mathrm{C}$.

The freezing point depression of each extender was measured with an Advanced Osmometer in milliosmols $/ \mathrm{kg}$ after the addition of citric acid. The milliosmols (mOs) were converted to freezing point depression values based upon sodium chloride standards at concentrations of 100 and $500 \mathrm{mOs} / \mathrm{kg}$ water. 
Experiment 1 was designed to evaluate two $\mathrm{CO}_{2}$ levels, $0.2 \mathrm{~g} \mathrm{CO}_{2}$ and $0.4 \mathrm{~g}$ $\mathrm{CO}_{2} / 100 \mathrm{ml}$, varying in $\Delta$ from -0.62 to $-0.82^{\circ} \mathrm{C}$ and -0.56 to $-0.79^{\circ} \mathrm{C}$, respectively. In Exp. 2, extenders with a higher $\mathrm{CO}_{2}$ level $(0.8 \mathrm{~g} / 100 \mathrm{ml})$ and a wider range in $\Delta\left(-0.44\right.$ to $\left.-1.02^{\circ} \mathrm{C}\right)$ were studied. Fluid to gas ratios in the containers between $1: 0$ and $1: 16 \mathrm{v} / \mathrm{v}$ were evaluated in Exp. 3, using an extender with a low $\mathrm{CO}_{2}$ level $(0 \cdot 2 \mathrm{~g} / 100 \mathrm{ml})$.

Eight White Leghorn females in individual cages were inseminated with $0.4 \mathrm{ml}$ of diluted or $0.1 \mathrm{ml}$ undiluted (control) semen per treatment. Comparisons of fertility were based on the eggs laid 2 to 8 days after a single insemination. The collection period was extended to the 15th day to determine duration of fertility, which was reported as the average number of days that the hens remained fertile. Fertility was determined by candling after 5 days of incubation. Data were analysed by analysis of variance and treatment comparisons were by the Duncan's Multiple Range Test (Steel \& Torrie, 1960).

\section{Experiment 1}

\section{RESULTS}

The fertility did not differ significantly for semen stored in extenders with $\Delta$ ranging from -0.62 to $-0.75^{\circ} \mathrm{C}$ (Table 2) and with a low $\mathrm{CO}_{2}$ content

\section{TABLE 2}

EFFECT OF $\mathrm{CO}_{2}$ LEVEL AND FREEZING POINT DEPRESSION ON FERTILITY OF FOWL SPERMATOZOA STORED FOR $24 \mathrm{hr}$ (EXPERIMENT 1 )* $\dagger$

\begin{tabular}{|c|c|c|c|c|c|c|c|c|c|c|}
\hline \multirow[b]{2}{*}{$\begin{array}{c}\text { Extender } \\
\text { No. }\end{array}$} & \multirow[b]{2}{*}{$\begin{array}{c}\mathrm{CO}_{2} \text { level } \\
(\mathrm{g} / 100 \mathrm{ml})\end{array}$} & \multirow{2}{*}{$\begin{array}{l}\text { Freezing point } \\
\text { depression }(\Delta) \\
\quad\left({ }^{\circ} \mathrm{C}\right)\end{array}$} & \multicolumn{6}{|c|}{ Percentage fertility } & \multirow{2}{*}{$\begin{array}{l}\% \\
\text { of hens } \\
\text { fertile }\end{array}$} & \multirow{2}{*}{$\begin{array}{c}\text { Duration } \\
\text { of } \\
\text { fertility } \\
\text { (Av. days) }\end{array}$} \\
\hline & & & $\begin{array}{c}\text { Trial } \\
1\end{array}$ & $\begin{array}{c}\text { Trial } \\
2\end{array}$ & $\begin{array}{c}\text { Trial } \\
3\end{array}$ & $\begin{array}{c}\text { Trial } \\
4\end{array}$ & $\begin{array}{c}\text { Trial } \\
5\end{array}$ & Mean $\ddagger$ & & \\
\hline $\begin{array}{l}1 \\
2 \\
3 \\
4 \\
5 \\
6 \\
7 \\
8\end{array}$ & $\begin{array}{l}0.2 \\
0.2 \\
0.2 \\
0.2 \\
0.4 \\
0.4 \\
0.4 \\
0.4\end{array}$ & $\begin{array}{l}-0.82 \\
-0.75 \\
-0.68 \\
-0.62 \\
-0.79 \\
-0.72 \\
-0.63 \\
-0.56\end{array}$ & $\begin{array}{l}33 \\
90 \\
78 \\
80 \\
89 \\
33 \\
63 \\
62\end{array}$ & $\begin{array}{l}60 \\
96 \\
76 \\
67 \\
64 \\
85 \\
92 \\
70\end{array}$ & $\begin{array}{l}53 \\
63 \\
77 \\
83 \\
51 \\
68 \\
58 \\
54\end{array}$ & $\begin{array}{l}63 \\
75 \\
91 \\
69 \\
51 \\
65 \\
78 \\
59\end{array}$ & $\begin{array}{l}69 \\
74 \\
68 \\
43 \\
76 \\
76 \\
83 \\
66\end{array}$ & $\begin{array}{l}55^{\mathrm{a}} \\
79^{\mathrm{b}} \\
78^{\mathrm{b}} \\
68^{\mathrm{a}} \mathrm{b} \\
65^{\mathrm{a}} \mathrm{b} \\
66^{\mathrm{a}} \mathrm{b} \\
75^{\mathrm{a}} \mathrm{b} \\
62^{\mathrm{a}} \mathrm{b}\end{array}$ & $\begin{array}{l}78 \\
92 \\
95 \\
95 \\
85 \\
88 \\
95 \\
83\end{array}$ & $\begin{array}{l}7 \cdot 9 \\
8 \cdot 6 \\
7 \cdot 2 \\
7 \cdot 6 \\
7 \cdot 9 \\
7 \cdot 7 \\
8 \cdot 5 \\
7 \cdot 1\end{array}$ \\
\hline \multicolumn{3}{|c|}{ Fresh undiluted control } & 88 & 98 & 98 & 98 & 92 & $96^{c}$ & 100 & $10 \cdot 4$ \\
\hline
\end{tabular}

* Semen stored at $2^{\circ} \mathrm{C}$ in Extenders 1 to 8 (Table 1)

† Fluid to gas ratio of $1: 7.2$ and bottle capacity of $34.4 \mathrm{ml}$.

$¥$ Mean of forty hens and 220 eggs (range of 208 to 229 eggs) per treatment. Means with a common letter are not significantly different from each other $(P<0 \cdot 05)$. Standard error is equal to $\pm 5.97 \%$.

$(0.2 \mathrm{~g} / 100 \mathrm{ml})$. However, an increase in the tonicity to $\Delta-0.82^{\circ} \mathrm{C}$ decreased $(P<0.05)$ the fertility. The highest level of fertility $(79 \%)$ with greater duration (8.6 days) was obtained in a solution with a $\Delta-0.75^{\circ} \mathrm{C}$.

No significant differences in fertility were found between semen samples stored in extenders with $\Delta$ ranging from -0.56 to $-0.79^{\circ} \mathrm{C}$ and with a $\mathrm{CO}_{2}$ content of $0.4 \mathrm{~g} / 100 \mathrm{ml}$. Fertility ranged from $58 \%$ to $92 \%$ with the best extender $\left(\Delta-0.63^{\circ} \mathrm{G}\right)$ at this $\mathrm{CO}_{2}$ level. The fresh undiluted semen gave higher $(P<0.05)$ fertility than extended semen stored for $24 \mathrm{hr}$. The duration 
of fertility and percentage of hens fertilized were also greater when using fresh undiluted semen.

\section{Experiment 2}

In trials 1 to 3 (Table 3 ), the fertility $(82 \%)$ was higher $(P<0.05)$ for semen stored in the extender with $\Delta-0.69^{\circ} \mathrm{C}$ than for semen stored in extenders with $\Delta$ ranging from -0.44 to $-0.62^{\circ} \mathrm{C}$.

\section{TABLE 3}

EFFECT OF FREEZING POINT DEPRESSION ON THE FERTILITY OF FOWL SPERMATOZOA STORED IN AN EXTENDER CONTAINING $0.8 \mathrm{~g} \mathrm{CO}_{2}$ PER $100 \mathrm{ml}$ EXTENDER (EXPERIMENT 2)*

\begin{tabular}{|c|c|c|c|c|c|c|c|c|c|c|c|}
\hline \multirow{2}{*}{$\begin{array}{c}\text { Extender } \\
\text { No. }\end{array}$} & \multirow{2}{*}{$\begin{array}{c}\text { Freezing point } \\
\text { depression }(\Delta) \\
\qquad\left({ }^{\circ} \mathrm{C}\right)\end{array}$} & \multicolumn{8}{|c|}{$\begin{array}{c}\text { Percentage fertility total eggs laid during Days } 2 \text { to } 8 \\
\text { after single insemination }\end{array}$} & \multirow{2}{*}{$\begin{array}{l}\% \\
\text { of hens } \\
\text { fertile }\end{array}$} & \multirow{2}{*}{$\begin{array}{c}\text { Duration } \\
\text { of } \\
\text { fertility } \\
\text { (Av. days) }\end{array}$} \\
\hline & & $\begin{array}{c}\text { Trial } \\
1\end{array}$ & $\begin{array}{c}\text { Trial } \\
2\end{array}$ & $\begin{array}{c}\text { Trial } \\
3\end{array}$ & Mean $\ddagger$ & $\begin{array}{c}\text { Trial } \\
4\end{array}$ & $\begin{array}{c}\text { Trial } \\
5\end{array}$ & $\begin{array}{c}\text { Trial } \\
6\end{array}$ & Meanf & & \\
\hline $\begin{array}{r}9 \\
10 \\
11 \\
12 \\
13 \\
14 \\
15\end{array}$ & $\begin{array}{l}-1.02 \\
-0.89 \\
-0.75 \\
-0.69 \\
-0.62 \\
-0.53 \\
-0.44\end{array}$ & $\begin{array}{l}- \\
- \\
85 \\
71 \\
42 \\
34\end{array}$ & $\begin{array}{l}- \\
- \\
\overline{77} \\
39 \\
53 \\
13\end{array}$ & $\begin{array}{l}- \\
\overline{-} \\
\overline{84} \\
51 \\
59 \\
39\end{array}$ & $\begin{array}{l}- \\
- \\
\overline{82^{\mathrm{ac}}} \\
54^{\mathrm{b}} \\
51^{\mathrm{bd}} \\
29^{\mathrm{c}}\end{array}$ & $\begin{array}{l}29 \\
64 \\
78 \\
89 \\
68 \\
- \\
-\end{array}$ & $\begin{array}{l}19 \\
57 \\
86 \\
83 \\
74 \\
- \\
-\end{array}$ & $\begin{array}{l}41 \\
75 \\
83 \\
88 \\
68 \\
- \\
-\end{array}$ & $\begin{array}{l}30^{\mathrm{a}} \\
65^{\mathrm{b}} \\
82^{\mathrm{ce}} \\
87^{\mathrm{ce}} \\
70^{\mathrm{d}} \\
- \\
-\end{array}$ & $\begin{array}{r}63 \\
88 \\
96 \\
100 \\
81 \\
83 \\
65\end{array}$ & $\begin{array}{l}6 \cdot 4 \\
8 \cdot 0 \\
8 \cdot 7 \\
7 \cdot 9 \\
7 \cdot 8 \\
6 \cdot 4 \\
4 \cdot 9\end{array}$ \\
\hline \multicolumn{2}{|c|}{ Fresh undiluted control } & 98 & 98 & 92 & $96^{e}$ & 84 & 75 & 97 & $85^{e}$ & 98 & $10 \cdot 3$ \\
\hline
\end{tabular}

* Stored $24 \mathrm{hr}$ at $2^{\circ} \mathrm{C}$ in Extenders 9 to 15 (Table 1).

+ Fluid to gas ratio $1: 7.2$ and bottle capacity of $34 \cdot 4 \mathrm{ml}$.

$¥$ Mean of twenty-four hens and 120 eggs (range of 106 to 138 eggs) per treatment. Means with a common letter are not significantly different from each other $(P<0.05)$. Standard errors are equal to $\pm 5 \cdot 81 \%$ (Trials 1 to 3 ) and $\pm 3 \cdot 81 \%$ (Trials 4 to 6 ).

TABLE 4

EFFECT OF FLUID TO GAS RATIO ON FERTILITY OF FOWL SPERMATOZOA STORED IN A $\mathrm{CO}_{2}$ EXTENDER (EXPERIMENT 3 )*

\begin{tabular}{|c|c|c|c|c|c|c|c|c|c|}
\hline \multirow{2}{*}{$\begin{array}{l}\text { Treatment } \\
\text { No. }\end{array}$} & \multirow{2}{*}{$\begin{array}{l}\text { Fluid : gas } \\
\text { ratio } \\
(m l)\end{array}$} & \multirow{2}{*}{$\begin{array}{c}\text { Bottle } \\
\text { capacity } \\
(m l)\end{array}$} & \multicolumn{5}{|c|}{$\begin{array}{l}\text { Percentage fertility total eggs laid during } \\
\text { Days } 2 \text { to } 8 \text { after single insemination }\end{array}$} & \multirow{2}{*}{$\begin{array}{c}\% \\
\text { of hens } \\
\text { fertile }\end{array}$} & \multirow{2}{*}{$\begin{array}{c}\text { Duration } \\
\text { of } \\
\text { fertility } \\
\text { (Av. days) }\end{array}$} \\
\hline & & & $\begin{array}{c}\text { Trial } \\
1\end{array}$ & $\begin{array}{c}\text { Trial } \\
2\end{array}$ & $\begin{array}{c}\text { Trial } \\
\mathbf{3}\end{array}$ & $\begin{array}{c}\text { Trial } \\
4\end{array}$ & Mean $\dagger$ & & \\
\hline $\begin{array}{l}1 \\
2 \\
3 \\
4 \\
5 \\
6\end{array}$ & $\begin{array}{l}1: 0 \cdot 0 \\
1: 1 \cdot 2 \\
1: 2 \cdot 0 \\
1: 3 \cdot 9 \\
1: 8 \cdot 1 \\
1: 16 \cdot 0\end{array}$ & $\begin{array}{l}13 \cdot 0 \\
13 \cdot 0 \\
13 \cdot 0 \\
34 \cdot 4 \\
34.4 \\
63.8\end{array}$ & $\begin{array}{l}36 \\
63 \\
70 \\
54 \\
71 \\
75\end{array}$ & $\begin{array}{l}67 \\
91 \\
74 \\
67 \\
87 \\
65\end{array}$ & $\begin{array}{l}43 \\
50 \\
63 \\
73 \\
84 \\
78\end{array}$ & $\begin{array}{l}33 \\
58 \\
52 \\
59 \\
58 \\
78\end{array}$ & $\begin{array}{l}44^{\mathrm{a}} \\
66^{\mathrm{b}} \\
65^{\mathrm{a}} \\
63^{\mathrm{a}} \\
76^{\mathrm{a}} \\
74^{\mathrm{a}}\end{array}$ & $\begin{array}{l}76 \\
84 \\
88 \\
94 \\
94 \\
94\end{array}$ & $\begin{array}{l}6 \cdot 0 \\
8 \cdot 0 \\
8 \cdot 0 \\
7 \cdot 8 \\
8 \cdot 2 \\
8 \cdot 2\end{array}$ \\
\hline 7 & \multicolumn{2}{|c|}{$\begin{array}{l}\text { Fresh undiluted } \\
\text { control }\end{array}$} & 98 & 86 & 93 & 90 & $92^{c}$ & 100 & $10 \cdot 1$ \\
\hline
\end{tabular}

* Stored $24 \mathrm{hr}$ at $2^{\circ} \mathrm{C}$ in Extender $2\left(\mathrm{CO}_{2}\right.$ level $\left.=0.2 \mathrm{~g} / 100 \mathrm{ml}\right)$.

$\uparrow$ Means of thirty-six hens and 178 eggs (range of 164 to 186) per treatment. Means with a common letter are not significantly different from each other $(P>0 \cdot 05)$. Standard error is equal to $\pm 5 \cdot 26 \%$.

In trials 4 to 6 , the highest average fertility $(87 \%)$ was again obtained with semen stored in the extender with $\Delta-0.69^{\circ} \mathrm{C}$. However, no significant differences in fertility were observed with semen stored in extenders with 
$\Delta-0.69^{\circ} \mathrm{C}$ and $\Delta-0.75^{\circ} \mathrm{C}$. An increase in the tonicity $\left(-0.89\right.$ to $\left.-1.02^{\circ} \mathrm{C}\right)$ or a decrease reduced $(P<0.05)$ the fertility of stored semen. The highest percentage of hens fertilized was with semen stored in hypertonic extenders of $\Delta-0.69^{\circ} \mathrm{C}$ and $\Delta-0.75^{\circ} \mathrm{C}$. The duration of fertility was longest using the latter extender.

\section{Experiment 3}

Fertility was reduced $(P<0.05)$ by storing diluted semen in a container with a fluid to gas ratio of 1:0 (Table 4). The highest fertility $(76 \%)$ was obtained with semen stored at a fluid to gas ratio of $1: 8 \cdot 1$ although that which was given additional gas space (1:16 fluid to gas ratio) was similar. The percentage of hens fertilized was increased by storage of semen at the higher fluid to gas ratios. The fertilizing capacity of semen stored for $24 \mathrm{hr}$ at all fluid to gas ratios was reduced $(P<0.05)$ below that of the fresh control.

\section{DISCUSSION}

The bottles that were used for the storage of carbonated semen were effective in preventing excessive $\mathrm{CO}_{2}$ loss. In previous experiments, the carbonated semen was stored in glass ampoules and $\mathrm{CO}_{2}$ loss occurred during the mixing process and transfer of the extender to the ampoules. Furthermore, all solutions were handled in the cold to reduce the amount of foaming or loss of $\mathrm{CO}_{2}$ upon the addition of citric acid. In the present experiments the foaming occurred but only after the bottles were capped, thus the $\mathrm{CO}_{2}$ was released into the gas space of the bottle and its loss was held to a minimum. The release of $\mathrm{CO}_{2}$ into the gas space probably caused a rise in $\mathrm{pH}$ which could influence the viability of the spermatozoa. The ratio of fluid to gas space would then become an important factor in storage experiments with carbonated extenders. Sodium citrate was used to vary osmotic pressure but not $\mathrm{pH}$.

Harris \& Hobbs (1964) noted that $\mathrm{CO}_{2}$ levels above $1.2 \mathrm{~g} / 100 \mathrm{ml}$ were not beneficial to the retention of the fertilizing capacity of fowl spermatozoa, except with the higher fluid to gas ratio in containers of $1: 6 \cdot 78$. In the present study, the fertility was higher with diluted semen stored at fluid to gas ratios in containers of $1: 8 \cdot 1$ to $1: 16$. The fertility was reduced $(P<0.05)$ by storage of carbonated semen in a bottle without any gas space. Based upon these results, a fluid to gas ratio in a container of $1: 6 \cdot 78$ or higher would appear to be best for the storage of fowl spermatozoa in carbonated extenders.

Tsukunaga \& Takahashi (1961) obtained a marked increase in fertility with fowl spermatozoa stored in hypertonic yolk-citrate extender. These findings were confirmed in earlier work at this laboratory with non-yolk and carbonated, non-yolk citrate extenders for fowl (Hobbs \& Harris, 1963a, b) and turkey (Harris et al., 1963) spermatozoa.

In general, the higher fertility in the present experiments with 0.2 to $0.8 \mathrm{~g}$ $\mathrm{CO}_{2}$ levels was obtained with semen stored in carbonated extenders varying in $\Delta$ from -0.68 to $-0.75^{\circ} \mathrm{C}$. The only exception was with spermatozoa stored at the $0.4 \mathrm{~g}$ level of $\mathrm{CO}_{2}$. The highest fertility with this $\mathrm{CO}_{2}$ level was with spermatozoa stored in an extender with a $\Delta$ of $-0.63^{\circ} \mathrm{C}$. These results 
differed markedly from those obtained earlier (Hobbs \& Harris, 1963b) where it was shown that the cold-ampoule method gave highest fertility when semen was stored in an extender with a $\Delta$ of $-1.06^{\circ} \mathrm{C}$. This difference may be related to the $\mathrm{CO}_{2}$ loss during handling.

The highest fertility for non-carbonated citrate extenders was with one having a $\Delta$ of $-0.79^{\circ} \mathrm{C}$ (Hobbs \& Harris, 1963a). With the control of $\mathrm{CO}_{2}$ loss in the present study the optimum $\Delta$ for carbonated extenders is near this value. No significant differences in fertility were observed between spermatozoa stored in carbonated extenders with $\Delta-0.69^{\circ} \mathrm{C}$ and $\Delta-0.75^{\circ} \mathrm{C}$ at the $0.8 \mathrm{~g}$ $\mathrm{CO}_{2} / 100 \mathrm{ml}$ level.

\section{ACKNOWLEDGMENT}

The authors are indebted to the American Poultry and Hatchery Federation for partial support of this research by a grant-in-aid.

\section{REFERENCES}

Burrows, W. H. \& Quin, J. P. (1937) Collection of spermatozoa from domestic fowl and turkey. Poultry Sci. 16, 19.

Harris, G. C., JR. \& Hobrs, T. D. (1964) The effects of fluid to gas ratio, dilution rate, and $\mathrm{CO}_{2}$ level on the fertilizing capacity of chicken spermatozoa stored in carbon dioxide extenders. Poultry Sci. 43, 529.

Harris, G. C., JR., Hobrs, T. D., Brown, J. E. \& Warren, L. B. (1963) The storage of turkey spermatozoa in sodium citrate and carbon dioxide extenders. Poultry Sci. 42, 536.

HobBs, T. D. \& Harris, G. C., JR. (1963a) Effect of freezing point depression and pH on motility and fertility of chicken spermatozoa stored in sodium citrate extenders. Poultry Sci. 42, 254.

Hobss, T. D. \& Harris, G. C., JR. (1963b) Effect of freezing point depression and $\mathrm{CO}_{2}$ on motility and fertility of chicken spermatozoa stored in carbon dioxide extenders. Poultry Sci. 42, 388.

Steel, R. G. D. \& Torrie, J. H. (1960) Principles and procedures of statistics. McGraw-Hill, New York.

Tsukunaga, S. \& Takahashi, T. (1961) The promotion of fertility rate of cock semen by adjusting the osmotic pressure of yolk-citrate buffer. Bull. Hiroshima agric. Coll. 1, 25.

WiLcox, F. H. \& Shaffner, C. S. (1957) Effect of differences in salt and hydrogen-ion concentration on the fertilizing ability of avian sperm. 7. appl. Physiol. 2, 429.

Yamane, J., Tsukunaga, S. \& Takahashi, T. (1962) A basic principal of make-up of the dilutor for fowl semen. Zootec. Vet. 17, 523. 